\title{
Eksistensi: Strategi Pengelolaan Industri Kerajinan Keramik Borneo Lentera Prima Singkawang
}

\author{
Iwan Pranoto ${ }^{1}$, Elvira ${ }^{2}$, Zakarias Sukarya Soeteja ${ }^{3}$ \\ ${ }^{1,2}$ Universitas Palangka Raya, Jl. Yos Sudarso, Palangka, Kec. Jekan Raya, Kota \\ Palangka Raya, Kalimantan Tengah 74874 \\ ${ }^{3}$ Universitas Pendidikan Indonesia, J1. Dr. Setiabudi No.229, Isola, Kec. Sukasari, \\ Kota Bandung, Jawa Barat 40154 \\ Email: ${ }^{1}$ pranotoiwan@fkip.upr.ac.id; ${ }^{2}$ mandau.talawang03@gmail.com; \\ ${ }^{3}$ zakarias@upi.edu
}

\begin{abstract}
ABSTRAK
Industri kerajinan keramik Borneo Lentera Prima merupakan pusat industri yang menaungi kelompok perajin di bidang keramik yang ada di daerah Singkawang. Industri ini merupakan tempat produksi barang keramik yang masih aktif dari beberapa kelompok industri lainnya. Kelompok industri kerajinan ini dapat bertahan dan mengembangkan diri. Hal itu didasari adanya sistem manajemen yang terkelola dengan baik, sehingga tetap bisa mempertahankan eksistensinya dalam dunia industri secara kreatif dan inovatif. Adapun tujuan dari kegiatan penelitian ini meliputi, konsep eksistensi yang dikembangkan dalam pengelolaan industri keramik Borneo Lentera Prima di Singkawang, dengan memperhatikan strategi pengelolaan pekerja, bentuk produk, dan strategi pemasaran. Metode yang digunakan dalam penelitian ini yaitu pendekatan interdisiplin dengan metode kualitatif studi kasus, dengan didukung beberapa disiplin ilmu seperti sosial budaya dan manajemen. Proses pengumpulan data diperoleh dari lapangan dengan cara pengamatan, wawancara, dan dokumentasi terkait serta relevan. Proses eksistensi yang dilakukan oleh manajemen industri kerajinan keramik Borneo Lentera Prima Singkawang meliputi sistem upah kerja yang sesuai, sehingga dapat membuat setiap perajin memiliki pendapatan yang sesuai dengan kebutuhan ekonomi. Tahapan eksistensi lainnya meliputi bentuk yang khas sebagai identitas budaya, sehingga memiliki daya tarik bagi pasar, namun dalam pencapaian keberhasilan dalam penjualan, manajemen melakukan strategi pemasaran yang meliputi sasaran, kebutuhan, keunggulan, dan pembaharuan.
\end{abstract}

Kata kunci: eksistesi, strategi, pengelolaan, keramik

\section{Existence: Management Strategy the Industry Craft Ceramic Borneo Lentera Prima Singkawang} ABSTRACT

The Borneo Lentera Prima ceramic handicraft industry is an industrial center that houses a group of craftsmen in the ceramic field in the Singkawang area. This industry is a production place for ceramic goods, which is still active from several other industrial groups. This handicraft industry group can survive and develop itself. This is based on the existence of a management system that is well managed so that it can maintain its existence in the industrial world, creatively and innovatively. This research activity includes the concept of existence developed in managing the Borneo Lentera Prima ceramic industry in Singkawang by paying attention to workermanagement strategies, product forms, and marketing strategies. The method used in this research is an interdisciplinary approach with a qualitative case study method, supported by several disciplines such as socio-culture, management. The data collection process was obtained from the field through observation, interviews, and related and relevant documents. The existing process carried out by the management 
of the Borneo Lentera Prima Singkawang ceramic craft industry includes an appropriate wage system to make every artisan have an income according to economic needs. Other stages of existence include a distinctive form as a cultural identity. It has an appeal to the market, but in achieving success in sales management, it undertakes a marketing strategy that includes goals, needs, excellence, and renewal.

Keywords: existence, strategy, management, ceramics

\section{PENDAHULUAN}

Pembuatan keramik Cina di Sakkok merupakan tradisi turun-temurun dari nenek moyang orang Cina yang dibawa ke Singkawang. Mereka merupakan orang Cina yang bekerja sebagai petani, nelayan, dan buruh kasar. Orang-orang Hakka memiliki kemampuan dan keterampilan, salah satunya dalam pembuatan kerajinan keramik. Setelah dibubarkannya kongsi emas oleh kaum kolonial pada abad ke 19, orang Cina di Singkawang pada masa itu beralih profesi, ada yang menjadi pedagang, petani, nelayan, serta perajin. Berdasarkan perkembangannya industri kerajinan keramik di Singkawang telah berkembang mulai dari 1933 hingga saat ini, perusahaan keramik yang masih eksis dalam dunia perindustrian pasar yaitu industri kerajinan keramik Borneo Lentera Prima.

Berdirinya industri kerajinan keramik Borneo Lentera Prima didasari adanya perusahaan sebelumnya yaitu Perusahaan Keramik Sinar Terang, industri keramik perusahaan ini kemudian membuka cabang yaitu kerajinan keramik Borneo Lentera Prima. Hal itu dikarenakan tingginya permintaan pasar, baik secara nasional hingga internasional, namun seiring perkembangannya perusahaan ini mengalami kemunduran dalam proses produksinya dan lebih memfokuskan pada bata merah guna kebutuhan bangunan. Melalui perkembangannya, industri kerajinan Borneo Lentera Prima-lah yang meneruskan untuk memproduksi barangbarang kerajinan keramik seperti guci, vas bunga, piring, dan mangkuk.

Berdasarkan perkembangannya, industri kerajinan keramik Borneo Lentera Prima masih tetap eksis hingga saat ini dalam memproduksi kerajinan keramik, meskipun sudah banyak industri lainnya yang memiliki kemampuan membuat kerajinan keramik yang serupa. Di dalam perkembangannya, industri kerajinan Borneo Lentera Prima mengembangkan eksistensinya melalui pengelolaan serta sistem manajemen yang baik. Menurut Mahendra (2017: 152) bahwa eksistensialis secara umum menekankan pentingnya kebebasan manusia dan pilihan kreatif serta inovatif, baik dalam penggunaan media sosial serta pendukung lainnya yang disesuaikan dengan kondisi perkembangan zaman. Dari pendapat yang dikemukakan bahwa pusat kerajinan Borneo Lentera Prima Singkawang selalu mengembangkan inovasi dan kreativitas dalam memimpin industri kerajinan keramik yang dimiliki Ibu Bong Lie Phin. 
Proses kreativitas dalam pengembangan sebuah industri di bidang seni memerlukan sebuah informasi yang disesuaikan dengan perkembangan zaman. Hal itu didasari dari beberapa konsep budaya, seperti yang disampaikan oleh Pranoto (2017: 180) bahwa nilai-nilai budaya masyarakat yang ada di kelompok perajin keramik Singkawang didasari oleh pentingnya peningkatan ekonomi dan kebutuhan ritual, sehingga memunculkan budaya kerja yang tinggi dan konsisten. Dari pendapat yang dikemukakan bahwa proses kreatif yang dilakukan oleh manajemen industri kerajinan keramik Borneo Lentera Prima perlunya memperhatikan kualitas pekerjaan yang dihasilkan oleh perajin yang bekerja pada industri keramik ini, dengan acuan upah kerja yang sesuai kompetensi kerja.

Dalam perkembangannya guna mempertahankan eksistensi dalam dunia industri keramik, manajemen Borneo Lentera Prima perlu memperhatikan strategi yang berkaitan dengan kondisi pasar, baik dalam negeri maupun luar negeri, sehingga keramik yang dihasilkan dapat diterima dan diminati oleh masyarakat. Seperti yang disampaikan oleh Simbolon (2013: 407) bahwa konsep strategi pemasaran global diperlukan pendekatan yang dapat diterapkan dan memperhatikan strategi pemasaran produk-produk yang telah berstandar internasional. Dari pendapat yang dikemukakan bahwa perlunya strategi pemasaran yang dilakukan oleh manajemen industri keramik Borneo Lentera Prima sebaiknya disesuaikan dengan perkembangan zaman dan kebutuhan pasar. Dari penjelasan yang telah disampaikan bahwa proses eksistensi dalam dunia industri khususnya kerajinan keramik Borneo Lentera Prima Singkawang dilakukan oleh dan dengan manajemen yang baik, sehingga dapat bertahan dan terus memproduksi barangbarang kerajinan keramik dan masih diminati oleh pasar, sehingga penulis mengangkat judul penelitian ini yaitu "Eksistensi: Bentuk Pengelolaan Industri Kerajinan Keramik Borneo Lentera Prima Singkawang”. Sehingga dikemukakan dan muncul beberapa rumusan masalah yang akan dibahas yaitu, bagaimana sistem manajemen industri kerajinan keramik Borneo Lentera Prima Singkawang? Bagian kedua yaitu bagaimana jenis produk yang diciptakan oleh industri kerajinan keramik Borneo Lentera Prima Singkawang? Ketiga yaitu bagaimana strategi pemasaran yang dilakukan oleh industri kerajinan keramik Borneo Lentera Prima Singkawang?

Berdasarkan dari permasalahan yang akan dibahas, bahwa dalam perkembangannya industri kerajinan keramik Borneo Lentera Prima Singkawang merupakan generasi terakhir dalam perkembangan industri keramik di Singkawang. Hal itu didukung karena terjadinya eksistensi dalam sebuah industri, yang dikelola oleh manajemen pada pusat kerajinan ini. Eksistensi dalam perkembangan industri kerajinan didasari oleh sebuah ide serta kondisi sosial budaya yang berkaitan dengan kebutuhan pasar industri. Seperti yang disampaikan oleh Raditiya (2014: 31) bahwa eksistensi merupakan sebuah tindakan yang dilakukan oleh manusia 
dengan tujuan untuk menunjukkan suatu identitas, kehadiran di lingkungan masyarakat. Dari pendapat yang dikemukakan bahwa proses eksistensi dilakukan oleh individu atau kelompok guna menyampaikan pesan, pengaruh sosial, serta identitas budaya sehingga dapat diakui keberadaannya.

Keberadaan sebuah industri kerajinan keramik Borneo Lentera Prima Singkawang diketahui oleh pasar serta konsumen. Hal itu dikarenakan terjadinya proses eksistensi yang telah dilakukan khususnya melalui karya keramik yang diciptakan oleh perajin dengan mempertahankan budaya Cina. Seperti yang disampaikan oleh Pranoto, et al. (2020: 118) bahwa berbagai macam bentuk keramik yang telah diciptakan perajin di Singkawang seperti guci dan piring dengan memunculkan budaya Cina, dan barang-barang kerajinan keramik tersebut digunakan oleh masyarakat Dayak untuk keperluan adat istiadat serta upacara tradisi. Dari pendapat yang dikemukakan bahwa keramik Singkawang telah lama dikenal dan eksis dalam keberadaannya sebagai nilai budaya pada kelompok masyarakat, sehingga sampai saat ini proses pembuatan kerajinan dilakukan karena adanya permintaan pasar sebagai kebutuhan adat dan budaya suatu kelompok masyarakat di Kalimantan dan sekitarnya.

Kerajinan keramik yang diciptakan oleh perajin yang ada di Singkawang terjadi secara turun-temurun sehingga sudah menjadi kebiasaan di lingkungan masyarakat perajin yang ada di industri kerajinan Borneo Lentera Prima. Keberadaan perajin merupakan bagian dari proses eksistensi karya keramik yang dikelola oleh industri, dengan adanya dukungan modal perusahaan yang dimiliki oleh pemilik usaha industri kerajinan keramik Borneo Lentera Prima. Hal itu dikarenakan tingginya pendapatan ekonomi yang dimiliki oleh perajin, sehingga memiliki keinginan dan menekuni dalam pembuatan barang-barang keramik, serta menjadi kebiasaan dan keterampilan. Seperti yang disampaikan oleh Rambalangi, et al. (2018: 4) bahwa suatu kelompok masyarakat memiliki kebiasaan berupa sifatsifat, budaya tradisi yang diturunkan dan terus dikembangkan oleh generasi penerusnya, dengan adanya tujuan tertentu yang dianggap memiliki dampak bagi kehidupan. Dari pendapat yang dikemukakan bahwa perajin keramik Borneo Lentera Prima Singkawang, memiliki kemampuan dalam pembuatan kerajinan keramik dengan mempertahankan nilai-nilai budaya Cina. Hal itu unik dan menjadikan industri kerajinan keramik dapat bertahan dan tetap eksis dalam pembuatan keramik, produk yang telah dipasarkan masih diminati oleh konsumen, sehingga berdampak pada pertumbuhan ekonomi perusahaan.

Dari beberapa pendapat yang telah dikemukakan dapat dijelaskan bahwa eksisnya industri keramik ini dikarenakan adanya suatu tindakan yang dilakukan berupa pesan sosial berkaitan dengan strategi pemasaran. Pada sisi lainnya, terjadinya idealisme dalam menciptakan produk keramik yang memiliki unsur budaya tradisi dan proses eksistensi lainnya yaitu sistem manajemen yang 
mengelola upah pekerja sesuai dengan kondisi ekonomi, sehingga masih dimiliki tenaga terampil dalam pembuatan barang-barang kerajinan keramiknya. Berikut ini konsep eksistensi dalam pengelolaan industri kerajinan keramik Borneo Lentera Prima.

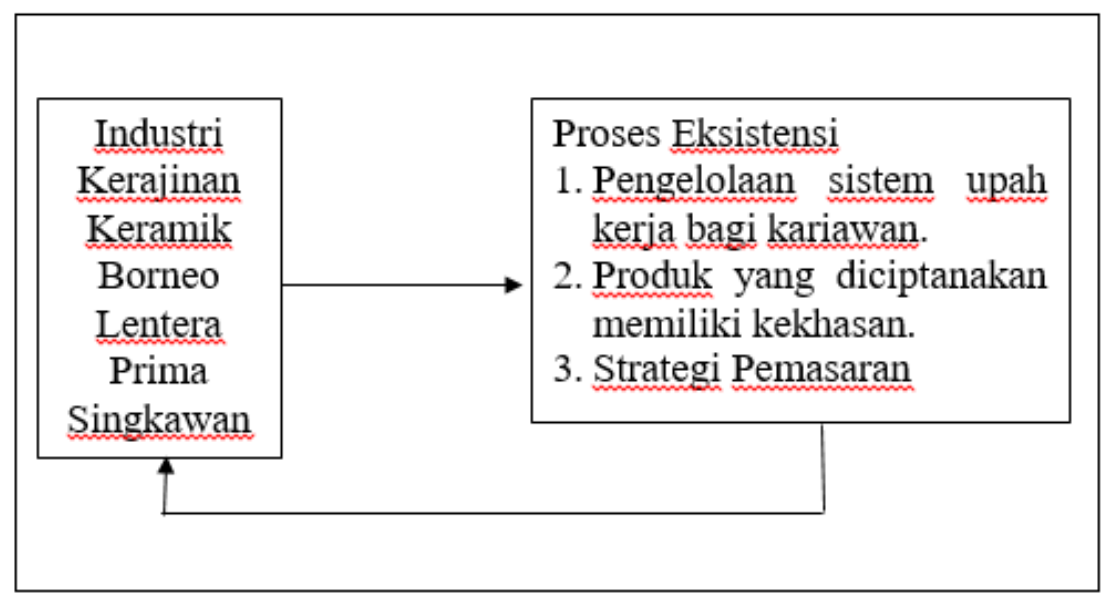

\footnotetext{
Gambar 1: Konsep Eksistensi dalam Pengelolaan Industri Kerajinan Keramik Borneo Lentera Prima Sumber: Adaptasi dari Raditiya (2014: 31)
}

\section{METODE}

Penelitian ini menggunakan pendekatan interdisiplin dengan metode kualitatif studi kasus, dengan didukung beberapa disiplin ilmu seperti sosial budaya, manajemen, dan seterusnya. Proses pengumpulan data diperoleh dari lapangan dengan cara pengamatan, wawancara, dan dokumen terkait serta relevan. Metode pendekatan studi kasus digunakan dalam strategi pengumpulan data, seperti yang disampaikan oleh Pranoto, et al. (2020: 228) bahwa dalam suatu penelitian untuk memastikan informasi berupa data yang diperoleh dari lapangan. Pada proses pengolahan data yang dihasilkan, diperlukan pengujian data atau dikenal dengan istilah keabsahan data, untuk mencapai suatu data yang terpercaya maka diperlukan triangulasi data yaitu: (a) triangulasi data, (b) triangulasi sumber, dan (c) triangulasi metode. Tahapan penyajian data mengacu pada sumber yang diperoleh pada saat di lapangan dan data yang telah menjawab rumusan masalah. Pada bagian kesimpulan dan verifikasi data, ditariklah suatu kesimpulan berdasarkan data-data yang diperoleh kemudian direduksi dan disajikan, berdasarkan permasalahan pada penelitian.

Dalam mengungkapkan masalah-masalah yang ada dalam penelitian ini, harus dilakukan secara jelas dan sesuai dengan apa yang ditemukan di lapangan dengan sejujurnya dan teliti, seperti yang disampaikan oleh Rohidi (2011: 72) yaitu 
“penelitian harus dilakukan dengan hati-hati, saksama, dan terinci”. Berikut ini adalah gambaran desain penelitian, yang akan dilakukan oleh peneliti:

Tabel 1. Metode Penelitian

\begin{tabular}{|c|c|c|c|c|}
\hline $\begin{array}{c}\text { Inti } \\
\text { Penelitian }\end{array}$ & $\begin{array}{l}\text { Masalah } \\
\text { Penelitian }\end{array}$ & $\begin{array}{c}\text { Jenis dan } \\
\text { Sumber Data }\end{array}$ & $\begin{array}{c}\text { Metode } \\
\text { Pengumpulan } \\
\text { Data }\end{array}$ & $\begin{array}{c}\text { Analisis } \\
\text { Data }\end{array}$ \\
\hline \multirow{3}{*}{$\begin{array}{l}\text { Eksistensi: } \\
\text { Strategi } \\
\text { Pengelolaan } \\
\text { Industri } \\
\text { Kerajinan } \\
\text { Keramik } \\
\text { Borneo } \\
\text { Lentera } \\
\text { Prima } \\
\text { Singkawang }\end{array}$} & $\begin{array}{l}\text { Bagaimana } \\
\text { sistem } \\
\text { manajemen } \\
\text { industri } \\
\text { kerajinan } \\
\text { keramik } \\
\text { Borneo } \\
\text { Lentera } \\
\text { Prima } \\
\text { Singkawang? }\end{array}$ & $\begin{array}{l}\text { - Pengelolaan } \\
\text { pegawai. } \\
\text { - Sistem upah } \\
\text { kerja. }\end{array}$ & $\begin{array}{l}\text { - Observasi } \\
\text { - Wawancara } \\
\text { - Dokumentasi } \\
\text { - Studi pustaka }\end{array}$ & $\begin{array}{l}\text { Deskriptif } \\
\text { Kualitatif }\end{array}$ \\
\hline & $\begin{array}{l}\text { Bagaimana } \\
\text { jenis produk } \\
\text { yang } \\
\text { diciptakan } \\
\text { oleh industri } \\
\text { kerajinan } \\
\text { keramik } \\
\text { Borneo } \\
\text { Lentera } \\
\text { Prima } \\
\text { Singkawang? }\end{array}$ & $\begin{array}{l}\text { - Bentuk } \\
\text { - Ragam hias } \\
\text { - Bahan }\end{array}$ & $\begin{array}{l}\text { - Observasi } \\
\text { - Wawancara } \\
\text { - Dokumentasi } \\
\text { - Studi pustaka }\end{array}$ & $\begin{array}{l}\text { Deskriptif } \\
\text { Kualitatif }\end{array}$ \\
\hline & $\begin{array}{l}\text { Bagaimana } \\
\text { strategi } \\
\text { pemasaran } \\
\text { yang } \\
\text { dilakukan } \\
\text { oleh industri } \\
\text { kerajinan } \\
\text { keramik } \\
\text { Borneo } \\
\text { Lentera } \\
\text { Prima } \\
\text { Singkawang? }\end{array}$ & $\begin{array}{l}\text { - Permintaan } \\
\text { pasar. } \\
\text { - Kekhasan } \\
\text { produk. } \\
\text { - Kebaruan } \\
\text { produk. }\end{array}$ & $\begin{array}{l}\text { - Observasi } \\
\text { - Wawancara } \\
\text { - Dokumentasi } \\
\text { - Studi pustaka }\end{array}$ & $\begin{array}{l}\text { Deskriptif } \\
\text { Kualitatif }\end{array}$ \\
\hline
\end{tabular}

Sumber: Pranoto (2017: 178) 


\section{HASIL DAN PEMBAHASAN}

\section{Proses Eksistensi yang Dikembangkan oleh Manajemen Industri Keramik Borneo Lentera Prima Singkawang}

Dalam perkembangan dunia industri yang dikelola oleh Bong Lie Phin khususnya kerajinan keramik Borneo Lentera Prima, memiliki sistem manajemen dan struktur organisasi. Hal itu dilakukan guna membentuk suatu proses profesional dalam dunia industri dengan adanya tujuan berupa visi dan misi serta menanamkan nilai-nilai filosofi, seperti yang disampaikan oleh Iskandar (2018: 23) bahwa pencapaian dengan strategi perusahaan, dapat melihat dari faktor pengelolaan sumber daya manusia yang diukur dari produktivitas sumber daya manusia secara individu dan secara teamwork yang terbentuk dalam struktur organisasi perusahaan. Berikut ini bentuk dari identitas industri kerajinan keramik Borneo Lentera Prima.

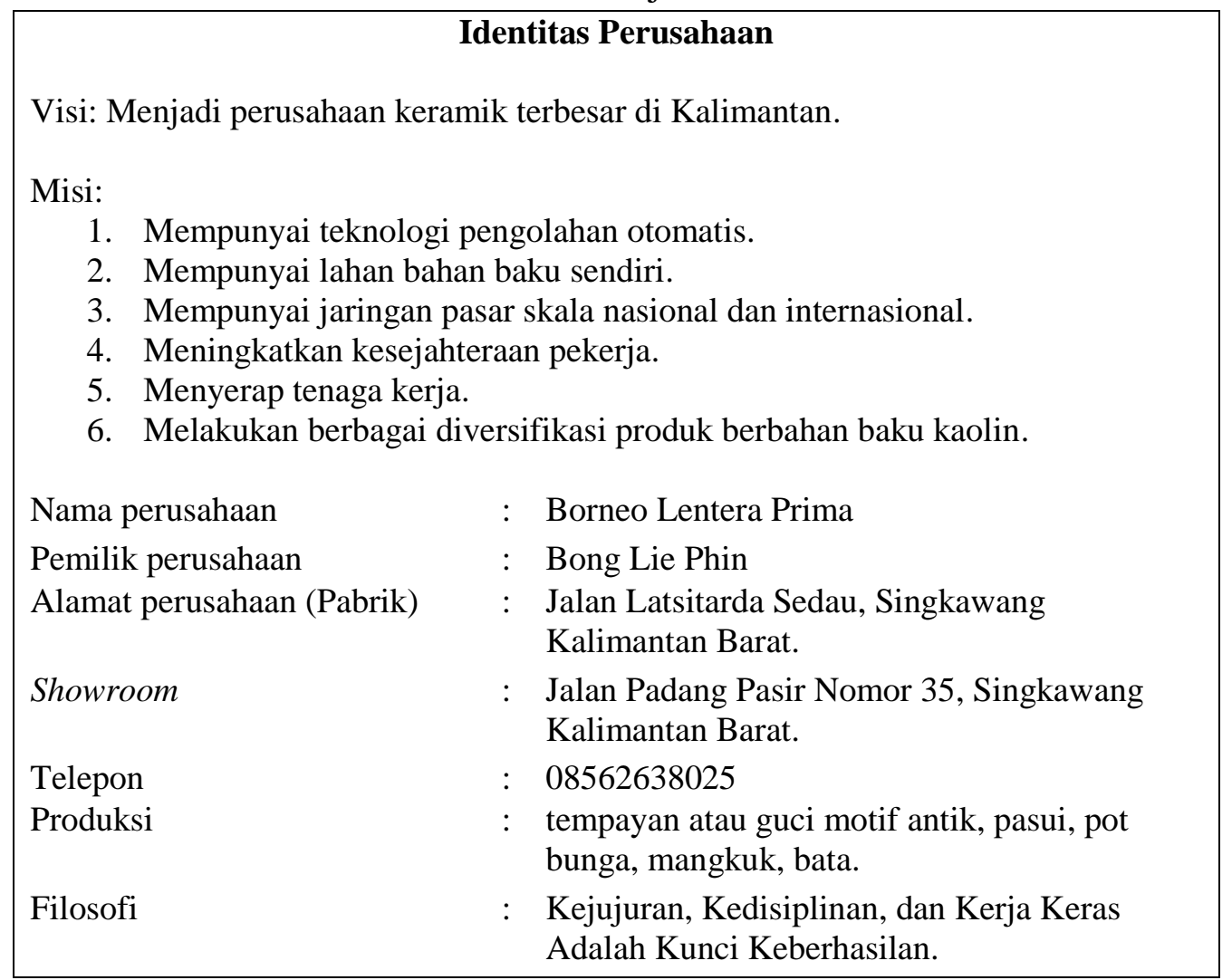

Gambar 2: Identitas Industri Kerajinan Keramik Borneo Lentera Prima Sumber: Arsip Perusahaan Borneo Lentera Prima, 2019

Perusahaan Borneo Lentera Prima menyusun struktur tingkatan atau kedudukan dalam suatu perusahaan. Dengan terbentuknya struktur perusahaan, mempermudah mengatur dan mengelola, serta memberikan tugas atau tanggung jawab atas pekerjaan serta perusahaan. Seperti yang disampaikan oleh Pranoto (2017: 180) bahwa sistem pengelolaan industri keramik di Singkawang selalu 
melibatkan kerja sama yang baik antara pekerja serta atasan. Dari pendapat yang dikemukakan bahwa proses kerja sama yang dilaksanakan oleh perajin dan sistem manajemen industri kerajinan keramik Borneo Lentera Prima memiliki dampak dalam strategi produksi, sehingga memberikan dampak positif bagi perajin, baik secara pendekatan budaya, ekonomi, dan sosial. Dalam pembentukan proses kerja sama antara perajin dengan pimpinan industri keramik Borneo Lentera Prima Singkawang maka, dibuatlah sebuah struktur penugasan berdasarkan kompetensi yang dimiliki oleh kelompok perajin dan manajemen pengelola industri. Berikut ini struktur organisasi perusahaan Borneo Lentera Prima.

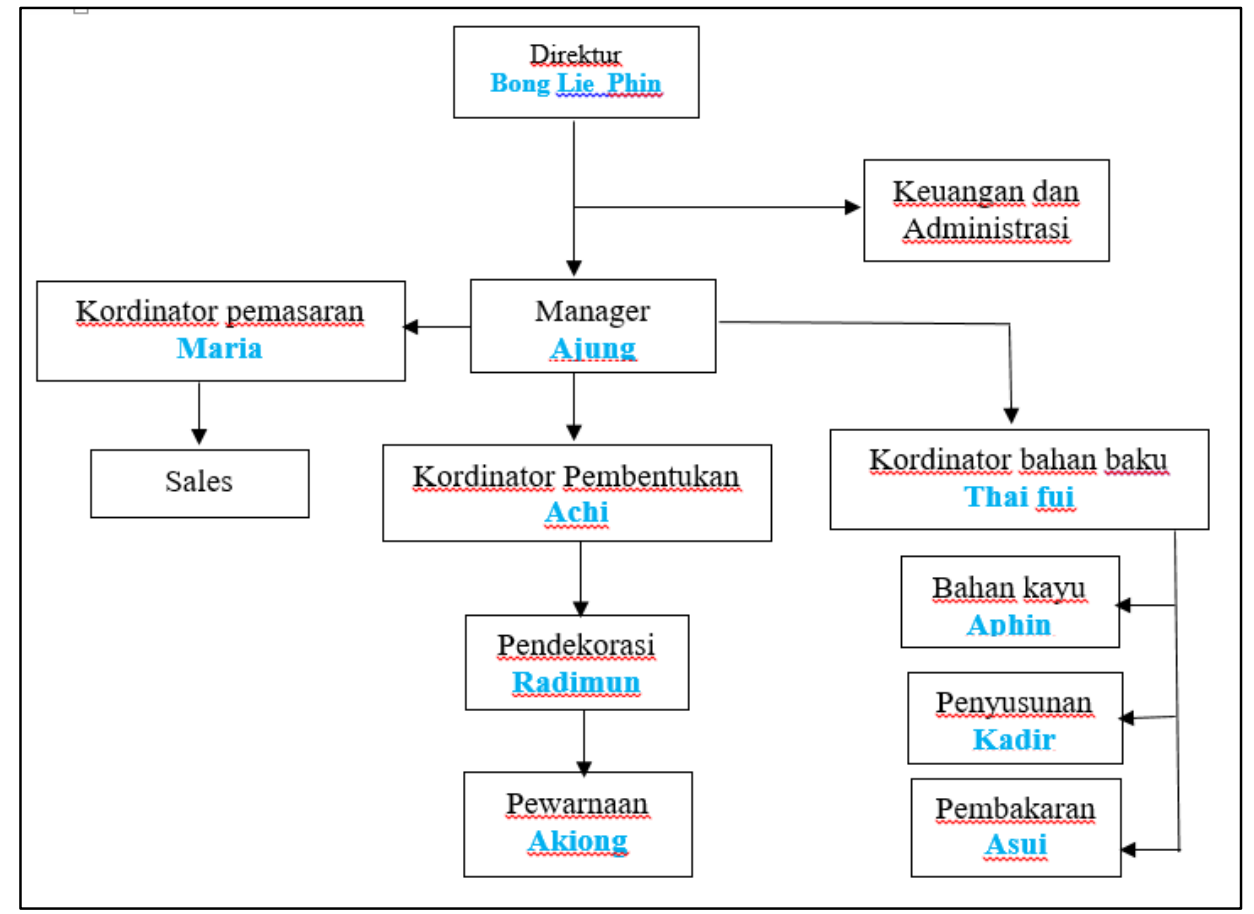

Gambar 3: Struktur Organisasi Perusahaan Borneo Lentera Prima Sumber: Perusahaan Borneo Lentera Prima, 2019

Dari struktur bagan yang telah dibentuk dalam pengelolaan industri kerajinan keramik Borneo Lentera Prima memiliki bagian-bagian yang telah ditetapkan kepada pekerja. Hal itu didasari oleh kompetensi yang dimiliki setiap individu, sehingga dapat dijalankan sesuai dengan tugasnya. Setiap bagian yang telah dimiliki pekerja pada pusat kerajinan ini memiliki upah kerja yang berbeda-beda, berdasarkan tingkat beban kerja yang dimiliki.

Pekerja yang memiliki keahlian dan keterampilan khusus pada industri kerajinan keramik Borneo Lentera Prima akan mendapatkan sebuah penghargaan yang diberikan oleh manajemen industri kerajinan ini. Hal itu menjadikan setiap pekerja selalu memiliki motivasi agar selalu terampil dalam membuat kerajinan keramik dengan tujuan mendapatkan bonus dari pimpinan. Seperti yang disampaikan oleh Iskandar (2018: 25) bahwa sistem pengelolaan pada suatu 
perusahaan dapat dilakukan dengan memperhatikan upah kerja yang sesuai dengan kapasitas pekerja. Dari pendapat yang dikemukakan bahwa sistem upah kerja yang dilakukan oleh manajemen industri ini dinilai berdasarkan jumlah karya kerajinan keramik yang mampu dibuat berdasarkan kelompoknya dan setiap upah akan dibayar dua kali dalam satu bulan. Berikut ini tabel sistem penggajian yang dilakukan oleh manajemen industri kerajinan keramik Borneo Lentera Prima.

\section{Tabel 2. Sistem Penggajian Perusahaan Borneo Lentera Prima}

\begin{tabular}{|c|c|c|c|}
\hline No & Jenis pekerjaan & Jumlah & Upah \\
\hline 1. & Membuat piring. & 1 piring & Rp 2.000,- \\
\hline 2. & Membuat mangkuk. & 1 mangkuk & Rp 1.500,- \\
\hline 3. & $\begin{array}{l}\text { Membuat guci (ukuran tinggi }=50 \mathrm{~cm} \text {, } \\
\text { lebar } 30 \mathrm{~cm} \text { ). }\end{array}$ & 1 guci & Rp 30.000,- \\
\hline 4. & $\begin{array}{l}\text { Penyambungan guci menjadi (ukuran } \\
\text { tinggi }=100 \mathrm{~cm} \text {, lebar } 50 \mathrm{~cm} \text { ). }\end{array}$ & 1 guci & Rp 35.000,- \\
\hline 5. & $\begin{array}{l}\text { Membuat dekorasi motif naga timbul dan } \\
\text { aksesori lainnya pada keliling permukaan } \\
\text { guci. }\end{array}$ & 1 guci & Rp 40.000,- \\
\hline 6. & Membuat tutup guci. & 1 tutup guci & Rp 5.000,- \\
\hline 7. & $\begin{array}{l}\text { Membuat motif manusia, tumbuhan, } \\
\text { hewan. }\end{array}$ & 1 guci & Rp 35.000,- \\
\hline 8. & $\begin{array}{l}\text { Jasa pembakaran keramik (menyusun } \\
\text { keramik dalam tungku naga, menyusun } \\
\text { kayu bakar proses pembakaran, proses } \\
\text { pembakaran, pembongkaran keramik dari } \\
\text { tungku naga). }\end{array}$ & 1 orang & Rp 700.000,- \\
\hline 9. & Proses glasir pada guci. & 1 guci & Rp 15.000,- \\
\hline 10. & Proses glasir pada mangkuk dan piring. & 1 piring / magkuk & Rp 1.000,- \\
\hline 11. & Membuat vas bunga. & 1 vas & Rp 15.000,- \\
\hline 12. & Upah pekerja harian. & 1 orang & Rp 85.000,- \\
\hline 13 & Penjaga gudang keramik. & $\begin{array}{l}1 \text { orang / } 2 \\
\text { minggu }\end{array}$ & Rp 500.000,- \\
\hline 14 & Karyawan distribusi di took. & $\begin{array}{l}1 \text { orang / } 2 \\
\text { minggu }\end{array}$ & Rp 700.000,- \\
\hline
\end{tabular}

Sumber: Borneo Lentera Prima (2019)

Dari uraian Tabel 2 mengenai harga upah yang diberikan oleh manajemen industri kerajinan keramik Borneo Lentera Prima Singkawang ini, merupakan suatu proses eksistensi yang terjadi. Hal itu dibuktikan dengan adanya pemberian upah yang sesuai dengan kebutuhan ekonomi bagi pekerja dalam menyelesaikan tugasnya membuat kerajinan keramik. Proses upah kerja yang didapatkan oleh perajin yang ada pada industri tersebut sudah dinyatakan layak berdasarkan kebutuhan ekonomi perajin. Seperti yang disampaikan oleh Iskandar (2018: 26) bahwa kepuasan pekerja dalam suatu perusahaan dikarenakan lingkungan yang menyenangkan dan mencintai pekerjaannya, sehingga mencapai moral kerja, kedisiplinan, prestasi kerja, dan upah pekerja. Dari pendapat yang dikemukakan 
bahwa sistem upah kerja yang dikelola oleh manajemen industri kerajinan keramik Borneo Lentera Prima Singkawang memperhatikan setiap aspek prinsip kerja, baik berupa moral, kesejahteraan, kedisiplinan, upah kerja, serta kepedulian terhadap pekerja.

Di dalam proses pekerjaan yang dilakukan, setiap pekerja memiliki pendapatan yang sangat memadai sehingga mempertahankan diri untuk tetap memilih profesi sebagai perajin keramik berdasarkan keahlian yang telah diwariskan oleh leluhurnya. Hal itu yang membuat industri kerajinan keramik Borneo Lentera Prima hingga saat ini tetap eksis dalam perindustrian keramik. Seperti yang disampaikan oleh Limawandoyo (2013: 9) bahwa manajemen produksi sebuah perusahaan akan tetap bertahan dengan memperhatikan kebutuhan pekerja, salah satunya upah yang sesuai, sehingga membuat setiap pekerja memberikan kualitas yang baik. Dari pendapat yang dikemukakan bahwa, dengan memperhatikan upah kerja, perajin keramik yang ada di lingkungan industri Borneo Lentera Prima dapat memberikan dampak baik berupa produktivitas dalam berkarya, sehingga industri kerajinan keramik akan terus eksis dalam memenuhi pasar.

\section{Jenis Produk yang Diciptakan oleh Industri Kerajinan Keramik Borneo Lentera Prima Singkawang}

Berkembangnya industri kerajinan keramik Borneo Lentera Prima di Singkawang, tidak lepas dari jenis-jenis produk yang diciptakan oleh perajin, sehingga beberapa keramik memiliki daya tarik tersendiri, khususnya guci-guci Cina dengan hiasan antik serta bentuk guci juga seperti antik. Seperti yang disampaikan oleh Mantondang, et al. (2018: 108) bahwa kekhasan budaya pada suatu kelompok masyarakat dapat memberi ciri serta daya tarik bagi kelompok masyarakat lainnya. Dari pendapat yang dikemukakan bahwa bentuk keramik yang diciptakan oleh perajin keramik di Perusahaan Borneo Lentera Prima merupakan sebuah produk budaya dengan mengembangkan kemampuan meniru guci-guci antik Cina.

Berbagai macam jenis produk keramik yang diciptakan oleh industri kerajinan keramik Borneo Lentera prima yaitu, guci, mangkuk, piring, vas bunga. Setiap produk yang dibuat memiliki ukuran yang berbeda-beda disesuaikan dengan produk yang telah dikembangkan sebelumnya dan bisa juga disesuaikan dengan permintaan konsumen. Saat ini produk terbesar yang dibuat oleh perajin yaitu guci dengan tinggi 1,5 meter dan lebar 60 centimeter, dengan ornamen naga serta beberapa motif flora. Produk-produk yang dibuat pada industri ini memiliki kekhasan sehingga memiliki daya tarik tersendiri, baik dari bentuk, ornamen, dan warna. 
Produk kerajinan yang telah diciptakan oleh perajin di Singkawang memiliki kekhasan, sehingga memiliki suatu daya tarik tersendiri bagi masyarakat pasar yang membeli kerajinan keramik perajin Singkawang. Hal itu dapat membuat eksisnya suatu produk budaya, khususnya kerajinan keramik yang diproduksi, sehingga sampai saat ini keberadaan industri kerajinan keramik Borneo Lentera Prima tetap eksis. Seperti yang disampaikan oleh Pratiwi, et al. (2018: 99) bahwa suatu kelompok masyarakat akan terus dikenal akan eksistensinya dengan mempertahankan suatu budaya berupa bahasa, seni, artefak peninggalan. Dari pendapat yang telah dikemukakan bahwa produk seni yang dikembangkan dengan mempertahankan kekhasannya maka, akan membuat produk seni dikenal masyarakat luas, sehingga akan selalu hadir eksistensinya. Hal itu menjadi tujuan yang dikembangkan oleh manajemen industri kerajinan keramik Borneo Lentera Prima Singkawang. Berikut ini gambar produk kerajinan keramik yang diciptakan dengan memiliki kekhasan budaya Cina.

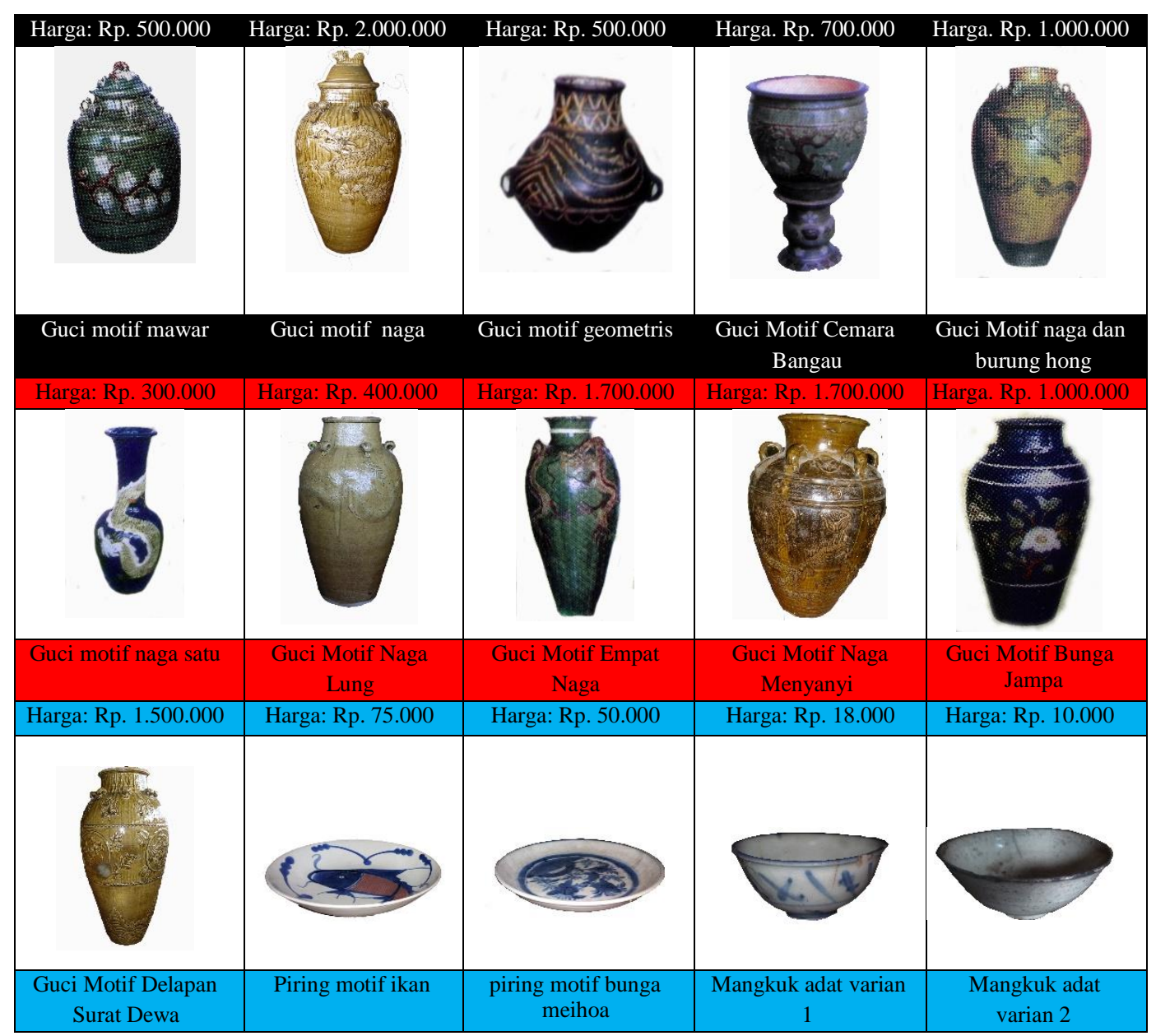

Gambar 4: Gambar produk kerajinan keramik yang memiliki kekhasan budaya Cina. Sumber: Borneo Lentera Prima, 2019 
Dari hasil produk kerajinan keramik yang telah diciptakan oleh perajin, terdapat kekhasan karya, sehingga masih diminati oleh pasar. Hal itu tidak lepas dari harga jual pada masyarakat yang dianggap masih terjangkau, dengan bentuk keramik etnik yang dibuat oleh perajin di lingkungan industri keramik Borneo Lentera Prima. Produk yang telah diproduksi dan diminati oleh pasar ini merupakan suatu langkah dalam menunjukkan eksistensi sebuah industri di bidang kerajinan keramik, sehingga memiliki daya tarik melalui produk yang dianggap mampu bersaing di pasar, dengan memperhatikan kekhasan budaya tradisional masyarakat Cina.

\section{Strategi Pemasaran yang Dilakukan oleh Industri Kerajinan Keramik Borneo Lentera Prima Singkawang}

Dalam pengelolaan strategi pemasaran yang dilakukan oleh manajemen industri kerajinan keramik Borneo Lentera Prima memiliki beberapa bagian yaitu, menjalin kerja sama dengan beberapa pengusaha atau tokoh yang memiliki keinginan menjual barang-barang keramik; kemudian memiliki showroom penjualan secara mandiri; bekerja sama dengan tim penjualan yang telah dibentuk oleh manajemen, dengan jangkauan yang sangat luas; menjalin kerja sama dengan jasa pengiriman barang, baik dalam dan luar negeri; dan kemudian seiring berkembangnya zaman, strategi pemasaran secara online.

Proses pemasaran keramik yang dilakukan oleh manajemen tidak lepas dari kondisi permintaan pasar dengan memperhatikan target pasar, seperti yang disampaikan oleh Suwityantini (2018: 71) bahwa dalam menentukan strategi pemasaran, karya seni perlu memperhatikan rencana pemasaran yang meliputi unsur sasaran, kebutuhan, keunggulan, dan kebaruan. Dari pendapat yang dikemukakan bahwa manjemen industri kerajinan keramik Singkawang memiliki strategi khusus dalam memasarkan produk-produk kerajinan keramik bernuansa budaya Cina, berikut ini strategi pemasaran yang dilakukan.

- Sasaran pemasaran secara lokal, nasional, dan internasional

Proses pemasaran yang dilakukan oleh manajemen industri keramik Borneo Lentera Prima dalam skala lokal, nasional, dan internasional yaitu adanya kerja sama yang dilakukan dengan tim pemasaran, sehingga barang-barang keramik yang telah jadi akan dilakukan proses distribusi kepada penjual yang menjalin kerja sama. Seperti yang disampaikan oleh Diniaty \& Agusrinal (2014: 181) bahwa dalam mencapai suatu strategi pemasaran diperlukan promosi dan kerja sama yang baik. Dari pendapat yang telah dikemukakan bahwa tahapan promosi dan menjalin kerja sama memerlukan suatu realsi yang terjalin lebih baik. Hal itu dilakukan guna menumbuhkan kepercayaan terhadap relasi, sehingga proses penjualan barangbarang keramik yang dilakukan oleh manajemen industri keramik dapat berjalan dengan baik, dan barang-barang keramik dapat didistribusikan kepada konsumen. 
Pada sisi lainnya, seiring perkembangan zaman, manajemen industri kerajinan keramik melakukan suatu pengembangan strategi pemasaran secara online. Hal itu dilakukan guna mempermudah kebutuhan pasar yang memiliki jangkauan lebih jauh dari setiap showroom kerja sama dengan manajemen industri kerajinan keramik Borneo Lentera Prima. Strategi pemasaran yang dilakukan secara online ini memerlukan suatu pembiasaan diri dalam mengembangkan marketing pasar online, sehingga tahapan ini diperlukan eksistensi agar produk yang dijual dapat dipahami dan dipercaya oleh konsumen.

- Kebutuhan pasar

Penggunaan barang-barang kerajinan keramik Singkawang pada masyarakat masih sanggat tinggi, baik dalam lingkungan lokal, nasional, maupun internasional. Seperti yang disampaikan oleh Pranoto, et al. (2020: 107) bahwa kerajinan keramik Singkawang diminati oleh masyarakat untuk kepentingan adat budaya, fungsi sehari-hari, dan kebutuhan interior. Dari pendapat yang telah dikemukakan bahwa produk kerajinan yang diproduksi, memiliki fungsi yang sangat tinggi bagi kebutuhan konsumen. Hal itu didasari dengan eksistensi dari bentuk keramik yang dianggap mampu memiliki nilai artistik dan pesan sosial dalam sebuah kelompok masyarakat, sehingga keramik Singkawang diminati oleh pasar.

- Keunggulan produk

Keramik yang diproduksi oleh perajin yang ada di Singkawang, memiliki keunggulan dari jenis keramik lainnya. Seperti yang disampaikan oleh Dinas Perindagkopnaker Kota Singkawang (2019) bahwa tanah liat yang digunakan merupakan mineral lempung kaolinite dan mempunyai komposisi hidrous aluminium silikat $\left(\mathrm{Al}_{2} \mathrm{O}_{3} \quad 2 \mathrm{SiO}_{2} 2 \mathrm{H}_{2} \mathrm{O}\right)$ dan mempunyai kandungan besi yang rendah. Ball Clay, yang merupakan jenis lempung sekunder berpartikel halus dan sangat plastis dengan kandungan mineral kaolinite (40-60\%), illite (18-33\%), kuarsa (7-22\%), dan mineral lainnya seperti carbon (1-4\%). Dari pendapat yang telah dikemukakan bahwa jenis tanah liat yang digunakan dapat menjadikan barang-barang keramik berkualitas tinggi.

Bentuk yang dimiliki keramik Singkawang memiliki ciri khas tersendiri dari jenis keramik lainnya. Seperti yang disampaikan oleh Sudiyati (2012: 563) bahwa kerajinan keramik Singkawang memiliki bentuk yang mengandung budaya Cina seperti motif dan bentuk. Dari pendapat yang dikemukakan bahwa, bagian dari keunggulan bentuk kerajinan keramik yang diproduksi oleh perajin yaitu adanya bentuk keramik yang khas, dengan memunculkan budaya Cina sebagai kekhasannya.

- Kebaruan produk

Karya kerajinan keramik Singkawang yang diciptakan guna kebutuhan pasar memiliki pengembangan bentuk serta ragam hias. Hal ini menjadikan keramik 
yang diproduksi tetap eksis dan selalu diminati oleh masyarakat. Berbagai macam jenis bentuk yang dapat dikembangkan berdasarkan permintaan konsumen, guna memenuhi kebutuhan pasar. Seperti yang disampaikan oleh Sari (2018: 4) bahwa dalam penjualan karya seni mesti memperhatikan permintaan pasar berupa produk, baik itu bentuk, warna, serta hiasan. Dari pendapat yang dikemukakan bahwa proses pengembangan bentuk, warna, dan ragam hias merupakan suatu langkah pembaruan pada produk kerajinan keramik yang telah diproduksi. Beberapa bentuk yang dikembangkan yaitu bentuk berupa ukuran pada guci, motif hias, dan warna. Hal itu dilakukan berdasarkan permintaan konsumen, sehingga produk kerajinan yang masuk pada permintaan pasar memiliki pembaruan dan tetap mempertahankan bentuk-bentuk kekhasan kriya keramik berbudaya Cina.

\section{KESIMPULAN}

Proses eksistensi merupakan suatu bagian dari kreativitas dalam mengembangkan sebuah industri di bidang seni, sehingga akan menimbulkan dampak positif dalam menjalankan sebuah usaha. Hal ini dilakukan oleh manajemen industri kerajinan keramik Borneo Lentera Prima, dengan memperhatikan eksistensi sebagai landasan pengembangan industri guna memenuhi kebutuhan pasar. Proses eksistensi yang dilakukan agar perusahaan tetap memproduksi barang keramik meliputi, terbentuknya jalinan kerja sama yang baik dalam pengelolaan individu-individu yang terlibat bekerja sama, baik berupa upah kerja, kesejahteraan, maupun fasilitas. Pada bagian sisi lainnya, proses eksistensi perlu dilakukan dengan memperhatikan kualitas karya kerajinan keramik yang dibuat, sehingga menjadi identitas dan kekhasan. Hal ini menjadikan bahwa keramik Singkawang memiliki daya tarik tersendiri dari industri keramik lainnya, dengan menonjolkan bentuk, warna, dan ragam hias. Proses eksistensi dilakukan dengan memperhatikan aspek pemasaran, sehingga masyarakat dengan mudah mendapatkan produk-produk kerajinan keramik, dengan mempertimbangkan sasaran pasar, kebutuhan pasar, keunggulan produk, serta kebaruan produk. 


\section{KEPUSTAKAAN}

Diniaty, Dewi ; Agusrinal, A. (2014). Perancangan Strategi Pemasaran pada Produk Anyaman Pandan. Jurnal Sains Teknologi Dan Industri, 11(2), 175-184. https://doi.org/http://dx.doi.org/10.24014/sitekin.v11i2.745

Iskandar, D. (2018). Strategi Peningkatan Kinerja Perusahaan Melalui Pengelolaan Sumber Daya Manusia dan Kepuasan Kerja dan Dampaknya Terhadap Produktivitas Karyawan. JIBEKA: Jurnal Ilmiah Bisnis Dan Ekonomi Asia, 12(1), 23-31. https://doi.org/https://doi.org/10.32812/jibeka.v12i1.8

Limawandoyo, E. A. (2013). Pengelolaan dan Pengembangan Sumber Daya Manusia pada PT Aneka Sejahtera Engineering. Jurnal Manajemen Bisnis Petra, 1(2), 8-18.

Mahendra, B. (2017). Eksistensi Sosial Remaja dalam Instagram (Sebuah Perspektif Komunikasi). Jurnal Visi Komunikasi, 16(1), 151-160. https://doi.org/http://dx.doi.org/10.22441/jvk.v16i1.1649

Mantondang, Armansyah; Lubis, Yurial Arief ; Suharyanto, A. (2018). Eksistensi Budaya Lokal dalam Usaha Pembangunan Karakter Siswa SMP Kota Padang Sidimpuan. Anthropos: Jurnal Antropologi Sosial Dan Budaya, 3(2), 103-116. https://doi.org/https://doi.org/10.24114/antro.v3i2.8306

Pranoto, Iwan; Pratiswa, Stephanus A.; \& Undiana, N. N. (2020). Motif Burung Enggang Gading pada Pakaian Adat Dayak Kanayatn Kalimantan Barat. Gorga: Jurnal Seni Rupa, 9(2), 226-231. https://doi.org/https://doi.org/10.24114/gr.v9i2.18928

Pranoto, Iwan ; Siahaan, V. D. ; Triyanto ; \& Rohidi, T. R. (2020). The Ceramics of Singkawang: Dayak Kanayatn's Cultural Perceptions in Kalimantan Barat. Mudra: Jurnal Seni Budaya, 35(1), 103-111. https://doi.org/https://doi.org/10.31091/mudra.v35i1.1006

Pranoto, I. (2017). Guci Cina di Singkawang (Kajian Visual dan Simbolik Reproduksi Kriya Keramik Guci di Desa Sakkok, Kecamatan Singkawang Selatan, Kota Singkawang, Kalimantan Barat). Prosiding Seminar Antar Bangsa, 175-188.

Pratiwi, Anisa E.; Triyono, Sugeng; Rezkiyanto, Imam; Asad, A. S. ; D., \& Khollimah, A. (2018). Eksistensi Masyarakat Adat di Tengah Globalisasi. Jurnal Civics, 15(2), 95-102. https://doi.org/10.21831/jc.v15i2.17289

Raditiya, M. H. B. (2014). Selfi dan Media Sosial pada Seni sebagai Wujud Eksistensi. JSP: Jurnal Ilmu Sosial Dan Ilmu Politik, 18(1), 26-38. https://doi.org/https://doi.org/10.22146/jsp.13096

Rambalangi; Sambiran, Sarah; Kasenda, V. (2018). Eksistensi Lembaga Adat dalam Pembangunan Kecamatan Tawalian Kabupaten Mamasa (Suatu Studi di Kecamatan Tawalian Kabupaten Mamasa Provinsi Sulawesi Barat). Jurnal Eksekutif: Jurnal Jurusan Ilmu Pemerintahan, 1(1).

Rohidi, T. R. (2011). Metodologi Penelitian Seni. Semarang: Cipta Prima Nusantara.

Sari, A. (2018). Analisis Teknik Pemasaran Karya Seni (Studi Kasus Go-Kuwang). Seminar Nasional Dan Call for Paper Sustainable Competitive Advantage (SCA) 8, 1-7.

Simbolon, F. (2013). Strategi Pemasaran Global di Pasar Indonesia. Jurnal Binus 
Business Review, 4(1), 405-413.

https://doi.org/https://doi.org/10.21512/bbr.v4i1.1406

Sudiyati, N. (2012). Keramik Singkawang Kalimantan Barat Kajian Aspek Estetika. Ilmu Budaya, Sekolah Pascasarjana Universitas Gadjah Mada Yogyakarta. Suwityantini, D. (2018). Strategi Pemasaran Karya Seni Lukis (Studi Kasus Pada Pameran Seni Rupa dan Pasar Seni Art Joga). Jurnal Ekobis Dewantara, 1(8), 67-77. Retrieved from http://jurnalfe.ustjogja.ac.id/index.php/ekobis/article/view/538\%3E

\section{Informan}

Maria (43 Tahun). Asisten Dinas Perindagkopnaker Kota Singkawang. 